\title{
Shear Strength of Reinforced Fibrous-self Compacted Concrete Box Girder using Recycled Concrete Aggregate
}

\author{
Mohammed A. Hadi*, Eyad K. Sayhood, Ali S. Resheq \\ Civil Engineering Department, University of Technology, Baghdad, Iraq. \\ *Corresponding author Email: $\underline{\text { 22391@student.uotechnology.edu.iq }}$
}

\section{H I G H L I G H T S}

- The recycled aggregate concrete mix shows decrease in the cylindrical compressive strength, splitting tensile strength, flexural strength, and elastic modulus of concrete.

- The RA has a significant effect on the load capacity of the box- girder without steel fibres.

- The test results showed that it is recommended to use Vf of $1.0 \%$ steel fiber with $100 \%$ RA to retain the NA concrete strength for the shear box-girder.

\section{A R T I C L E I N F O}

Handling editor: Wasan I. Khalil

Keywords:
Shear behavior
Box girder
Recycled aggregate
Steel fiber
Internal diaphragms

\author{
A B S T R A C T
}

Protection of environmental and conservation of natural resources is a fundamental issue in today's world. In this research, the shear behavior of reinforced concrete box girders with recycled aggregate (RA), steel fiber, and internal diaphragms were investigated. Eleven reinforced concrete box girders with typical longitudinal and transverse reinforcement were tested under two point loading until failure. The RA was prepared by crushing the collected waste of concrete from the laboratory test cylinders and cubes. The experimental variables considered include; RA percent of $50 \%, 75 \%$, and $100 \%$ (replacing from NA), steel fiber with volumetric ratios (Vf) of $0.5 \%, 1.0 \%$, and $2 \%$, diaphragm numbers (two and three). The test results revealed that the shear strength of the box girders affected by the RA content, the ultimate load was decreased by $(32,25$, and 19$) \%$ for the $(1 \cdots, 75$, and 0.$) \%$ RA concrete, respectively in compared with the control specimen. In contrast the steel fiber was more effective in strengthening of the RA concrete specimen, for the (Vf) of $0.5 \%, 1.0 \%$, and $2.0 \%$ with non-fibrous $100 \%$ RA concrete, the strengthening were $(25,40$, and 77$) \%$ respectively. Moreover, when $1.0 \%$ steel fibers added to the $1 . \%, 75 \%$, and $0 . \%$ RA concrete respectively, the strengthening were ( 4 . ,45 ,and48 $\%$ compared each with its reference specimen. On the other hand, when two and three diaphragms used, the strengthening for the non-fibrous $100 \%$ RA concrete was ( $6 \%$ and $9 \%)$ respectively. cracking load, ultimate load, loaddeflection, and concrete surface strain has been taken into consideration in this research.

\section{Introduction}

Concrete is the most important construction material which has been applied in all sorts of construction work in all over the world. At present, the consumption of the natural aggregate per year is around 8 to 12 billion tons. In the future, the demand of natural aggregate will increase due to rapid the construction of building, bridges, and roadways. The huge consumption of the natural aggregate as commercial and domestic construction will definitely deteriorated the environment. Therefore there is an urgent need to limit the use of natural aggregate [1]. Moreover, the old superstructures and infrastructures create huge amount of construction waste and demolition, which is dumped in the landfills, causing serious environmental hazards. The rarity of natural resources of aggregates and limited space of landfills bring attention to the conception of the recycling the concrete waste to fabricate recycled aggregates (RA) as a possible substitute of natural aggregates (NA) [2]. The using of recycled aggregate in the production of concrete is still restricted to non- structural usage such as roadway subbase. The lower quality of the recycled aggregate compared with the natural aggregate results in a decrease in the mechanical performance of the concrete [3]. Numerous studies have inspected the effect of the recycled aggregate on the performance of the concrete. Almost all the researchers reported that the replacement of NA by RA in concrete produced higher porosity and water absorption, lower strength and elastic modulus [4, 5, and 6]. Different solution have been proposed to solve the reduction in the strength resulting from the applying of RA in concrete, such reducing the water to cement ratio, increasing the cement content, strengthening the old adhered mortar attached to the RA by adding steel fiber, and adding fly ash [7]. Adding steel fiber into RA concrete is an effective method to recover the defect of RA concrete [8,9]. In which steel fibers working on 
prevent crack growth and formation through its bridging and help to prevent brittle fracture throughout increasing the tensile strength and toughness [10]. Furthermore, box girders are often used in bridges due to their stability, construction economy, and structural qualifications. Box girder is either rectangular or trapezoidal cross section. It can be constructed as single, double, or multi cell [11]. Self-compacting concrete (SCC) is defined as the concrete which has capability to flow under its own weight to fill the form completely, it has the ability to spread throughout the congested reinforcement. Also, it provides an adequately and dense homogeneous material without using vibrating. [12].Therefore, the SCC is suitable to use in the box girderstructure.Adding fibers adversely affect SCC workability and thus more dosage of super plasticizer should be adds to stay within the standard limits [13].

\section{Materials}

In this research the materials were tested at the Building Research Directorate before using;

1) Cement: local ordinary Portland cement (type I) was used in this research, the physical and chemical analysis properties are in agreement with the Iraqi specification No.5/ 1984 [14].

2) Fine aggregate: natural sand (al-ukhaideer) with maximum size of (4.75)mm was used in the present work. The specific gravity, sulphate content, absorption and fineness modulus of fine aggregate are within the Iraqi specification limits No.45.1984 [15].

3) Natural coarse aggregate (NA): natural crushed gravel with maximum size (12.5)mm was used. After washing and drying in the air, it was used in saturated surface dry condition. The grading of the coarse aggregate is within the requirement of ASTM.C33 [16].

4) Recycled aggregate (RA): the process started by breaking the old concrete which collected from the laboratory test cubes and cylinders by the mechanical hammer then crushing it by the crusher machine, then, the obtained RA was sieved to get the wanted size with a grading similar to that of the NA grading, with maximum size of $12.5 \mathrm{~mm}$, finally it washed and dried. The grading of the RA is within the requirements of the ASRM. C33 [16].

5) Reinforcing steel bars: in this research, two sizes of deformed steel bars were applied. For the main longitudinal reinforcement, steel bar size of $12 \mathrm{~mm}$ diameter and $540 \mathrm{MPa}$ yield stress is used, and bar size of $6 \mathrm{~mm}$ with $504 \mathrm{MPa}$ yield stress was used for the transverse reinforcement.

6) Steel fiber: micro steel fibers with tensile strength of $2850 \mathrm{MPa}$ (as stated in technical data sheet) and Aspect ratio of (75) were used.

7) Water: for the mixing and the curing of concrete specimens, tap water was used.

8) Limestone powder: was applied as cement partially replaced for the self-compacting mixes to improve the properties for the cement mix. The physical and the chemical properties have been taken into consideration.

9) Superplasticizers: in the present experimental work, superplasticizer type SikaVisco Crete-5930L was used.

\section{Specimen's description}

In this research the experimental work includes of casting and testing eleven simply supported RC box girders. All the typical specimens were with a length of $2000 \mathrm{~mm}$, and the same cross section of ; overall depth of 200mm, top flange width $450 \mathrm{~mm}$, one web thickness $60 \mathrm{~mm}$, top flange thickness and bottom flange thickness $60 \mathrm{~mm}$, and bottom flange width $300 \mathrm{~mm}$. A rectangular shape of cork with dimensions of (180mm width, $80 \mathrm{~mm}$ depth, and 2000mm length) was used for making the box girder shape. All specimens were reinforced with $4 \varnothing 12 \mathrm{~mm}$ bar for the main longitudinal bars at the bottom flange and $6 \mathrm{~mm}$ for the top flange, for stirrups bar of $6 \mathrm{~mm}$ was used. Figure 1.Illustrates the typical box girder specimen.
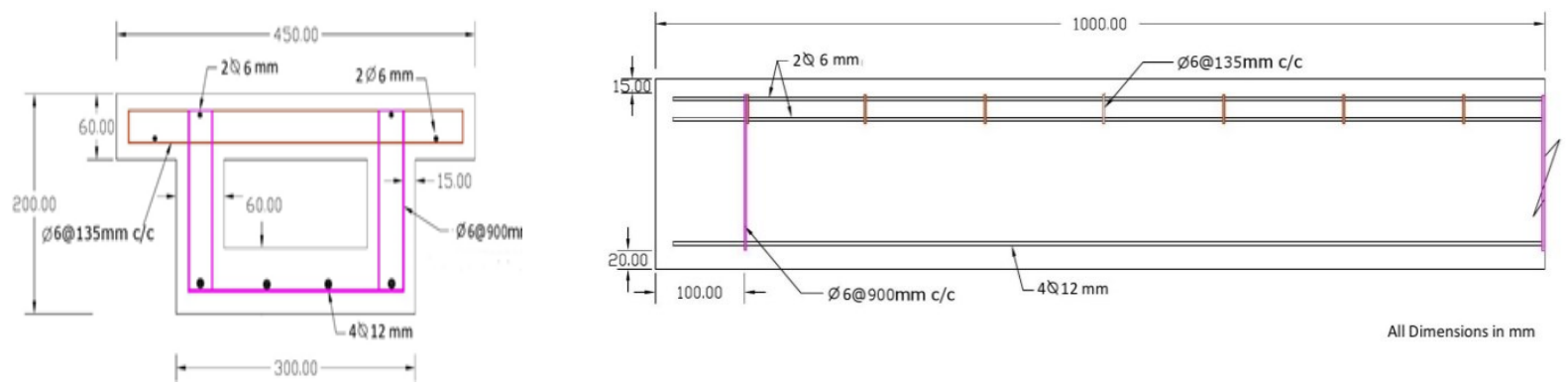

Figure 1: Typical rectangular box girder with reinforcement details

Box girders dimensions designed within the limitations of the AASHTO LRFD 2012 [17]. According to section (5.14.2.3.10a), (5.14.2.3.10b) for the minimum flange thickness and minimum web thickness respectively, while section (5.14.2.3.10c) for length of top flange cantilever. The length and depth of box girder must be within the limitation of $(1 / 5>\mathrm{d} / \mathrm{L}>1 / 30)$ forthe overall section limitation of AASHTO LRFD 2012[17]. Where: L and $\mathrm{d}$ is the length (support to 
support) and depth of the box girder respectively. The steel reinforcement is design in according to the American Concrete Institute (ACI-318M-14) [18].

\section{Box girder specimen's Identification}

There is a series of numbers and letters to identify the box girder specimens, which refer to the type of the shear box girder by letters $\mathrm{SH}$, the letter ( $\mathrm{N}$ or $\mathrm{R}$ ) refer to the type of the coarse aggregate (natural or recycled), while the steel fiber was referred by the letter $(\mathrm{F})$. As well, the numbers $(50,75$ and 100) and $(0.5,1.0,2.0)$ represented the RA and the steel fibers percentage, respectively. Furthermore, the letter (D) refers to the diaphragm, in which (D2 and D3) represent the specimen with two and three diaphragms respectively.

\section{Box girder specimen group's classification.}

Eleven shear box girders were divided into five groups as illustrated below;

1) Group A: consists of one specimen only, design with (100\%)NA.

2) Group B: consists of three specimens only, with $(50 \%, 75 \%$, and $100 \%)$ RA, respectively.

3) Group C: consists of three specimens only, (100\%)RA with $(0.5,1.0$ and 2.0$) \%$ steel fiber ratio (Vf) respectively.

4) Group D: consists of two specimens only, the first specimen was cast with (50\%)RA and (1.0\%)steel fiber, while the second specimen with (75\%)RA and (1.0\%)steel fiber.

5) Group E: consists of two specimens only, it was casted with non-fibrous (100\%)RA and (two diaphragms located (under the two points load), three diaphragms located (one at the middle and two under the two points load )), respectively. With typical cross-section of $60 \mathrm{~mm}$ width and $200 \mathrm{~mm}$ depth and reinforced with $6 \mathrm{~mm}$ longitudinal bars(two at the bottom and two at the top) and four of $6 \mathrm{~mm}$ stirrups bar.

\section{Box girder specimen's preparation.}

\subsection{Concrete mix design.}

Self-compacting concrete (SCC) was used for casting the specimens because of the small thickness of the box girder section. Several trial mixes were done according to the European Guidelines for (SCC) EFNARC [19].The concrete mixes were designed to achieve a cylinder compressive strength of $35 \mathrm{MPa}$ at 28 days age for the $(100 \%)$ NA concrete. The other eight mixes were all set with different percentage of RA and steel fiber, Table 1. illustrates the details of the selected trial mixes.

Table 1: Details of SCC trial mix

\begin{tabular}{|c|c|c|c|c|c|c|c|c|c|c|c|}
\hline $\begin{array}{c}\mathbf{G r} \\
\text { ou } \\
\text { p } \\
\text { Ty } \\
\text { pe }\end{array}$ & $\begin{array}{l}\text { Box Girder } \\
\text { designation }\end{array}$ & $\begin{array}{c}\text { Ceme } \\
\text { nt } \\
\mathrm{kg} / \mathrm{m}^{3}\end{array}$ & $\begin{array}{c}\text { Limesto } \\
\text { ne } \\
\text { Powder } \\
\mathrm{kg} / \mathrm{m}^{3}\end{array}$ & $\begin{array}{c}\text { Sand } \\
\mathrm{kg} / \mathrm{m}^{3}\end{array}$ & $\begin{array}{l}\mathrm{NA} \\
\mathrm{kg} / \\
\mathrm{m}^{3}\end{array}$ & $\underset{\mathrm{kg} / \mathrm{m}^{3}}{\mathrm{RA}}$ & $\begin{array}{l}\mathbf{V f} \\
\%\end{array}$ & $\begin{array}{c}\text { Wat } \\
\text { er } \\
\mathbf{L} / \mathbf{m} \\
3\end{array}$ & $\begin{array}{c}\text { Super- } \\
\text { plastisize } \\
\mathbf{r} \\
\mathbf{L} / \mathbf{m}^{3}\end{array}$ & $\begin{array}{c}\mathrm{W} / \\
\mathbf{C}\end{array}$ & $\mathbf{W} / \mathbf{P}$ \\
\hline $\mathrm{A}$ & SH-N-F0 & 430 & 120 & 790 & 800 & --- & 0 & 185 & 7.0 & 0.43 & 0.34 \\
\hline \multirow{3}{*}{ B } & SH-R50-F0 & 430 & 120 & 790 & 400 & 400 & 0 & 185 & 7.4 & 0.43 & 0.34 \\
\hline & SH-R75-F0 & 430 & 120 & 790 & 200 & 600 & 0 & 185 & 7.6 & 0.43 & 0.34 \\
\hline & SH-R100-F0 & 430 & 120 & 790 & --- & 800 & 0 & 185 & 7.8 & 0.43 & 0.34 \\
\hline \multirow{3}{*}{$\mathrm{C}$} & SH-R100-F0.5 & 430 & 120 & 790 & --- & 800 & 0.5 & 185 & 8.1 & 0.43 & 0.34 \\
\hline & SH-R100-F1.0 & 430 & 120 & 790 & --- & 800 & 1 & 185 & 8.3 & 0.43 & 0.34 \\
\hline & SH-R100-F2.0 & 430 & 120 & 790 & --- & 800 & 2 & 185 & 8.8 & 0.43 & 0.34 \\
\hline \multirow{2}{*}{$\mathrm{D}$} & SH-R75-F1.0 & 430 & 120 & 790 & 200 & 600 & 1 & 185 & 8.1 & 0.43 & 0.34 \\
\hline & SH-R50-F1.0 & 430 & 120 & 790 & 400 & 400 & 1 & 185 & 7.9 & 0.43 & 0.34 \\
\hline
\end{tabular}

\subsection{Mixing procedure}

The concrete was mixed in the structural laboratory at the University of Technology by using a horizontal rotary mixer with capacity of $0.12 \mathrm{~m}^{3}$, the mixing steps of the SCC is illustrated by: First the material were weighted and packed in bags. The mixer was cleaned and wetted before using. Adding the coarse and the fine aggregate to the mixer with (1/3) water and mixing for a minute. The limestone powder and cement were added to the mixer with quantity $(1 / 3)$ water and mixing for a minute. The last (1/3) of water mixed well with the superplasticizer, added little by little to the mixer and left for a minute. The steel fibers then sprayed to the mix gradually during the mixing.

\subsection{Molds manufacturing}

Plywood sheets of thickness $16 \mathrm{~mm}$ were used for the specimen's molds. The mold's base and corners were supported by wood strips (50*50) mm cross section. High pressure cork with section dimension of (180*80) mm was used to make the hole of the box-girder: it was fixed inside the steel cage and spaced equally by spacers. 


\subsection{Casting and curing}

Eleven batches of concrete were made to cast the box girders. Each batch was used to cast one box girder with three cylinders of $(100 * 200) \mathrm{mm}$ to determine the compressive strength at age of 28 days (standard test was done according to ASTM C39[20]), three cylinders of $(100 * 200) \mathrm{mm}$ for the splitting tensile strength test (standard test was done according to ASTM C496[21]). Three prisms of $(100 * 100 * 400) \mathrm{mm}$ were cast to determine the flexural strength test (standard test was done according to ASTM C78-02[22]). Two cylinders $(150 * 300) \mathrm{mm}$ were cast to measure the elastic modulus of concert (standard test was done according to ASTM C469-02a [23]). After 24 hours, the specimens were stripped from the molds and then burlap sacks and layer of bubble plastic were placed over and kept wet for 28 days, Figure 2 shows the casting of box girder specimens, Figure3.shows the curing for the specimens.

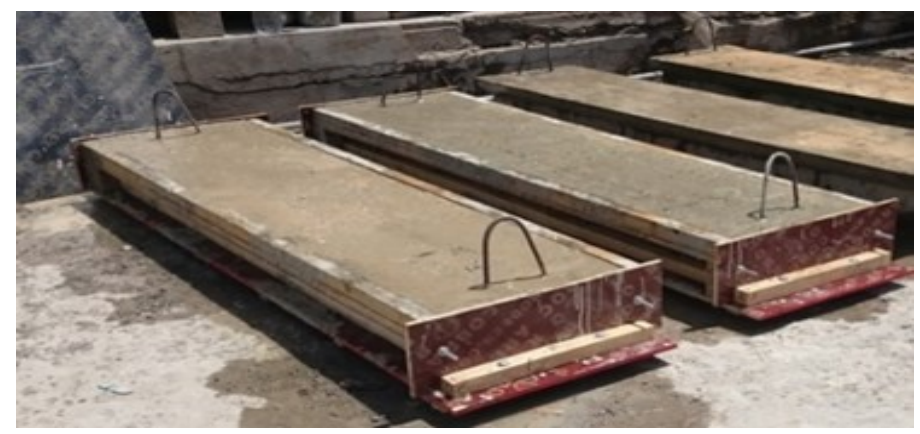

Figure 2: Casting of box girder specimens

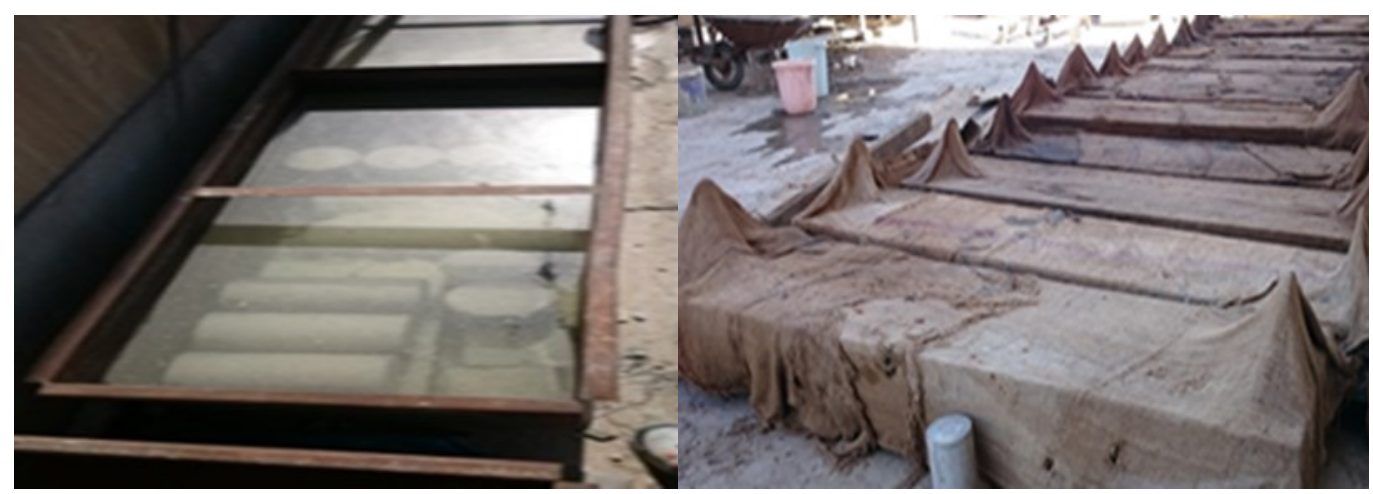

a) Control specimens

b) Box girder specimens

Figure 3: Curing of control and box girder specimens

\subsection{Surface preparing}

To prepare the box girder specimens for testing, concrete surface was smoothening by sandpaper to remove any loss material, washed and leave it to dry, all the specimens were painted with white water paint. Finally positions of the supporting, loading, and concrete surface strain gauges were marked.

\section{Testing of box girder specimens}

Eleven simply supported box girder specimens loaded by two line load applied at the third span, were tested in the structural laboratory of the civil engineering of the university of technology, using a $(2500 \mathrm{kN})$ capacity compression testing machine (AVERY).

Two steel beams have used to apply two- line loads. Rubber strips were used between the steel beams and the concrete surface, and between the concrete surface and the supports to avoid the local failure. Before placing the specimen inside the testing machine, the concrete surface strain gauges were fixed at the required positions. Six strain gauges were used for each specimen, three at each side through the shear zone with angle of 40 degree from the horizontal line as shown in Figure 4, and the specimens were labeled. For measuring the mid-span deflection, linear displacement transformer (LDT) was used. Data logger type (CONTROLS) was used after connecting the strain gauges cables and the (LDT)'s cables to the data logger and connect the last to the PC to read the deflection data by the LDT and the strain data which measured by the strain gauges. After completing the preparation of the specimens, the specimens were tested under a constant loading with average of ( $2 \mathrm{kN})$ from the beginning of the test until the failure. 


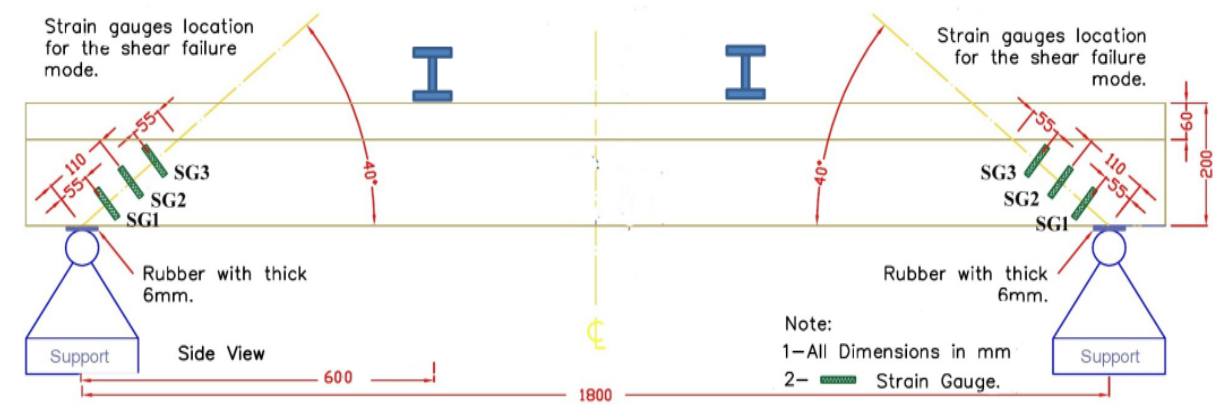

Figure 4: The locations for the concrete strain gauges

\section{Mechanical properties of control specimens}

The control specimens were tested directly after the box girder test. Table 2, shows the test results for the control specimens. Each result is average of three specimens test.

Table 2: The test results for the control specimens

\begin{tabular}{ccccc}
\hline $\begin{array}{c}\text { Box Girder } \\
\text { Designation }\end{array}$ & f́c (MPa) & $\begin{array}{c}\text { Splitting tensile strength } \\
\text { (MPa) }\end{array}$ & $\begin{array}{c}\text { Modulus of rupture } \\
\text { (MPa) }\end{array}$ & $\begin{array}{c}\text { Modulus of elasticity } \\
\text { (MPa) }\end{array}$ \\
\hline SH-N-F0 & 36 & 3.49 & 3.91 & 28771 \\
SH-R50-F0 & 32.0 & 3.04 & 3.36 & 26812 \\
SH-R75-F0 & 30.60 & 2.91 & 3.21 & 25552 \\
SH-R100-F0 & 28.79 & 2.75 & 3.0 & 24671 \\
SH-R100-F0.5 & 34.23 & 3.44 & 3.69 & 28618 \\
SH-R100-F1.0 & 36.62 & 3.61 & 3.84 & 30345 \\
SH-R100-F2.0 & 41.21 & 3.95 & 4.23 & 32983 \\
SH-R75-F1.0 & 39.57 & 3.86 & 4.13 & 31735 \\
SH-R50-F1.0 & 41.85 & 4.1 & 4.4 & 33957 \\
SH-R100-D2 & 28.93 & 2.78 & 3.13 & 24682 \\
SH-R100-D3 & 28.72 & 2.76 & 3.08 & 24678 \\
\hline
\end{tabular}

It is clear that, in comparison with the control specimen the compressive strength, flexural strength, splitting tensile strength, and the elastic modulus decrease with increasing the percent of RA, may this belong to the existing of porosity in the RA concrete which it is more than that for the NA concrete, also, the amount of the weak bond area in the RA concrete. Furthermore, in comparison with the non-fibrous $100 \% \mathrm{RA}$, the strengthening by the steel fibers is more significant by the $(0.5 \%, 1.0 \%, 2.0 \%)$ respectively, this may because that when the fiber is added concrete retained some of its lost strength and fibers act as a bridge at cracks which delaying the cracking appearance and the propagation which led to an increase in its strength.

\section{Experimental test results}

Table3 shows the test results of the box girder specimens in terms of the cracking load (Pcr), ultimate load (Pu), deflection at cracking load $(\delta \mathrm{cr})$, and deflection at ultimate load $(\delta \mathrm{u})$.

Table 3: The test results for the box girder specimens

\begin{tabular}{ccccc}
\hline Box Girder Designation & Pcr(kN) & Pu(kN) & ocr(mm) & 反u(mm) \\
\hline SH-N-F0 & 30 & 78 & 1.12 & 9.98 \\
SH-R50-F0 & 24 & 63 & 1.02 & 9.6 \\
SH-R75-F0 & 22 & 58 & 0.91 & 8.91 \\
SH-R100-F0 & 20 & 53 & 0.88 & 8.27 \\
SH-R100-F0.5 & 26 & 66 & 1.05 & 9.71 \\
SH-R100-F1.0 & 31 & 94 & 1.11 & 9.96 \\
SH-R100-F2.0 & 38 & 84 & 1.25 & 11.88 \\
SH-R75-F1.0 & 34 & 93 & 1.20 & 10.45 \\
SH-R50-F1.0 & 38 & 56 & 1.31 & 8.92 \\
SH-R100-D2 & 22 & 58 & 0.92 & 8.93 \\
SH-R100-D3 & 23 & & 0.98 & \\
\hline
\end{tabular}




\subsection{Cracking load (Pcr)}

Table 4.3 ustrates the effect of $(100,75$, and 50) \% RA ratios for the (0, and 1.0$) \%$ steel fiber on the first cracking load, Table 5. shows the effect of $(0.5,1.0$, and 2.0$) \%$ steel fiber for the $100 \%$ RA on the first cracking load, and Table 6 Represents the effect of diaphragms on the first cracking load.

Table 4: The effect of $(100,75$, and 50) \% RA ratios for $(0$, and 1.0$) \%$ steel fiber on the first cracking load

\begin{tabular}{cccccc}
\hline $\begin{array}{c}\text { Box Girder } \\
\text { Designation }\end{array}$ & $\begin{array}{c}\text { Pcr } \\
\mathbf{( k N )}\end{array}$ & $\begin{array}{c}\text { \% decrease in first } \\
\text { cracking load } \\
\text { relative to } \\
\text { (SH-N-F0 })\end{array}$ & $\begin{array}{c}\text { Box Girder } \\
\text { Designation }\end{array}$ & $\begin{array}{c}\text { Pcr } \\
\text { (kN) }\end{array}$ & $\begin{array}{c}\text { \% Increase in first } \\
\text { cracking load } \\
\text { relative } \\
\text { to (SH-N-F0 ) }\end{array}$ \\
\hline SH-N-F0 & 30 & ---- & SH-N-F0 & 30 & ---- \\
SH-R100-F0 & 20 & 33 & SH-R100-F1.0 & 31 & +3 \\
SH-R75-F0 & 22 & 27 & SH-R75-F1.0 & 34 & +13 \\
SH-R50-F0 & 24 & 20 & SH-R50-F1.0 & 38 & +27 \\
\hline
\end{tabular}

From the experimental results, it can be seen that for the box girders without steel fiber the influence of the RA is significant: compared with the control specimen, the decrease for the first cracking load are (33, 27, and 20) \% for the RA of $(100,75$, and 50$) \%$ respectively. On the other hand the strengthening of the recycled aggregate concrete box girders by steel fiber was significantly effective in increasing the first cracking load, the increases is $(3,13$, and 27$) \%$ for $(100,75$, and 50$) \%$ RA box girders strengthened with steel fiber ratio of $(1.0) \%$.

Table 5: The effect of $(0.5,1.0$, and 2.0$) \%$ steel fiber for the $100 \%$ RA on the first cracking load

\begin{tabular}{cccc}
\hline $\begin{array}{c}\text { Box Girder } \\
\text { Designation }\end{array}$ & $\begin{array}{c}\mathbf{P}_{\mathbf{c r}} \\
(\mathbf{k N})\end{array}$ & $\begin{array}{c}\text { \%Increase in first cracking load } \\
\text { relative to (SH-R100-F0) }\end{array}$ & $\begin{array}{c}\text { \% Increase in first cracking load } \\
\text { relative to (SH-N-F0 ) }\end{array}$ \\
\hline SH-N-F0 & 30 & ---- & --- \\
SH-R100-F0 & 20 & --- & -33 \\
SH-R100-F0.5 & 26 & 30 & -13 \\
SH-R100-F1.0 & 31 & 55 & +3 \\
SH-R100-F2.0 & 38 & 90 & +27 \\
\hline
\end{tabular}

In comparison with the non-fibrous (100) \% RA box girder, the strengthening by steel fiber is significantly effective in increasing the first cracking load. The increases is $(30,55$, and 90$) \%$ for (100) \% RA box girders strengthened with steel fiber ratios of $(0.5,1.0$, and 2.0$) \%$, respectively. On the other hand, in comparison with the control specimen when same amount of steel fibers used for the $100 \%$ RA box girders lead to strengthening of $(-13,+3$, and +27$) \%$, respectively.

Table 6: The effect of diaphragms on the first cracking load

\begin{tabular}{cccc}
\hline $\begin{array}{c}\text { Box Girder } \\
\text { Designation }\end{array}$ & $\begin{array}{c}\mathbf{P}_{\mathbf{c r}} \\
\mathbf{( k N )}\end{array}$ & $\begin{array}{c}\text { \%Increase in first cracking load } \\
\text { relative to (SH-R100-F0) }\end{array}$ & $\begin{array}{c}\text { \% Increase in first cracking load } \\
\text { relative to (SH-N-F0 ) }\end{array}$ \\
\hline SH-N-F0 & 30 & ---- & ---- \\
SH-R100-F0 & 20 & ---- & -33 \\
SH-R100-D2 & 22 & 10 & -27 \\
SH-R100-D3 & 23 & 15 & -23 \\
\hline
\end{tabular}

It is clear that when the recycled aggregate concrete box girder is strengthened by two of 60mm concrete diaphragms, the cracking load is lower than the one when using three diaphragm for the same second third of the box girder, where the increase in Pcr compared with girder without diaphragm is (10,and 15$) \%$ respectively.

\subsection{Ultimate load (Pu)}

Table 7. illustrates the effect of $(100,75$, and 50) \% RA ratios with the (0, and 1.0$) \%$ steel fiber on the ultimate load, Table 8. Shows the effect of $(0.5,1.0$, and 2.0$) \%$ steel fiber with the $100 \%$ RA on the ultimate load, and Table 9.represents the effect of diaphragms on the ultimate load.

Table 7: The effect of $(100,75$, and 50) \% RA ratios with the (0, and 1.0) \% steel fiber on the ultimate load

\begin{tabular}{|c|c|c|c|c|c|}
\hline $\begin{array}{l}\text { Box Girder } \\
\text { Designation }\end{array}$ & $\begin{array}{c}\mathbf{P u} \\
(\mathbf{k} \\
\mathbf{N})\end{array}$ & $\begin{array}{l}\text { \% decrease in ultimate load } \\
\text { relative to (SH-N-F0) }\end{array}$ & $\begin{array}{l}\text { Box Girder } \\
\text { Designation }\end{array}$ & $\begin{array}{c}\mathbf{P u} \\
(\mathbf{k} \\
\mathbf{N})\end{array}$ & $\begin{array}{c}\text { \% Increase in ultimate load } \\
\text { relative to(SH-N-F0 ) }\end{array}$ \\
\hline SH-N-F0 & 78 & ---- & SH-N-F0 & 78 & ---- \\
\hline SH-R100-F0 & 53 & 32 & SH-R100-F1.0 & 74 & -5 \\
\hline SH-R75-F0 & 58 & 25 & SH-R75-F1.0 & 84 & +8 \\
\hline SH-R50-F0 & 63 & 19 & SH-R50-F1.0 & 93 & +19 \\
\hline
\end{tabular}

From the experimental results, it can be seen that for the box girders without steel fiber the influence of the RA is significant: compared with the control specimen, the decrease for the ultimate load are $(32,25$, and 19) \% for the RA (100, 75, and 50) \% respectively. On the other hand, the strengthening of the recycled aggregate concrete box girders by steel fiber is 
significantly effective in increasing the ultimate load. The increases is $(-5,+8$, and +19$) \%$ for $(100,75$, and 50$) \%$ RA box girders strengthened with steel fiber ratio of $(1.0) \%$.

Table 8: The effect of $(0.5,1.0$, and 2.0$) \%$ steel fiber for the $100 \%$ RA on the ultimate load

\begin{tabular}{cccc}
\hline $\begin{array}{c}\text { Box Girder } \\
\text { Designation }\end{array}$ & $\begin{array}{c}\mathbf{P}_{\mathbf{u}} \\
(\mathbf{k N})\end{array}$ & $\begin{array}{c}\text { \%Increase in ultimate load relative } \\
\text { to (SH-R100-F0) }\end{array}$ & $\begin{array}{c}\text { \% Increase in ultimate load relative to } \\
\text { (SH-N-F0 ) }\end{array}$ \\
\hline SH-N-F0 & 78 & ---- & ---- \\
SH-R100-F0 & 53 & --- & -32 \\
SH-R100-F0.5 & 66 & 25 & -15 \\
SH-R100-F1.0 & 74 & 40 & -5 \\
SH-R100-F2.0 & 94 & 77 & +21 \\
\hline
\end{tabular}

In comparison with the non-fibrous (100) \% RA box girder, the strengthening by steel fiber is significantly effective in increasing the ultimate load. The increase is $(25,40$, and 77$) \%$ for $(100) \%$ RA box girders strengthened with steel fiber ratios of $(0.5,1.0$, and 2.0$) \%$, respectively. While, in comparison with the control specimen and the same amount of steel fiber ratios used for the $100 \%$ RA box girders, the increase is $(-15,-5$, and +21$) \%$ respectively.

Table 9: The effect of diaphragms on the ultimate load

\begin{tabular}{cccc}
\hline Box Girder Designation & $\begin{array}{c}\mathbf{P}_{\mathbf{u}} \\
(\mathbf{k N})\end{array}$ & $\begin{array}{c}\text { \% Increase in ultimate load relative } \\
\text { to (SH-R100-F0) }\end{array}$ & $\begin{array}{c}\text { \% Increase in ultimate load relative to } \\
\text { (SH-N-F0) }\end{array}$ \\
\hline SH-N-F0 & 78 & ---- & ---- \\
SH-R100-F0 & 53 & --- & -32 \\
SH-R100-D2 & 56 & 6 & -28 \\
SH-R100-D3 & 58 & 9 & -25 \\
\hline
\end{tabular}

Also, it is clear that when the recycled aggregate concrete box girder is strengthened by two of $60 \mathrm{~mm}$ concrete diaphragms, the ultimate load is lower than the one when using three diaphragms, where the increase in Pu compared with girder without diaphragm is $(6$,and 9$) \%$ respectively. In contrast, the decrease is $(28$, and 25$) \%$ respectively, in comparison with the control specimen.

In conclusion, as the percent of RA increases both Pcr and Pu decreases due to the reduction in concrete strength and splitting tensile strength. On the other hand, when the fibers is added, retained some of its lost strength and fibers can be act as a bridge at cracks in which delay the propagation and crack appearance which lead to an increase in both Pcr and Pu. When diaphragms are used, the flexural stiffness of the girder is increased and thus the Pcr and Pu are increased.

\subsection{Load-mid-span deflection behavior}

Figure 5.illustrates the load -mid-span deflection curves of the NA concrete (control) specimen with the (100, 75, and $50) \%$ RA concrete specimen. The specimen with more recycled aggregate showed larger deflection than the other specimens at the same loading level. This in turn affects the load carrying capacity of the box girder. On the other hand, there is a reduction in the deflection when (1.0) \% steel fiber adds, as shown in the Figure 6.

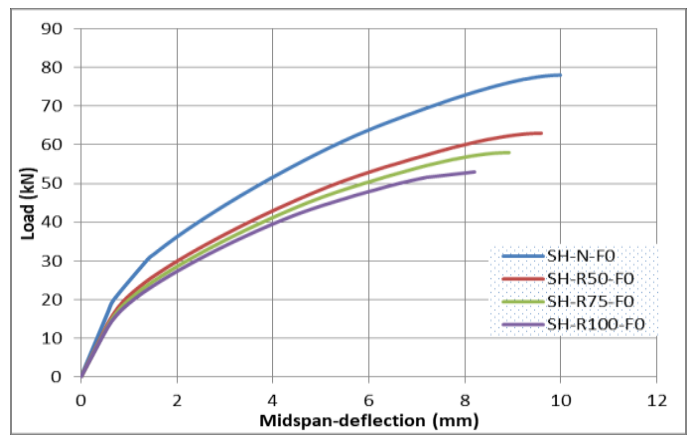

Figure 5: Effect of $(100,75,50) \%$ RA content on The LoadDefection Curve

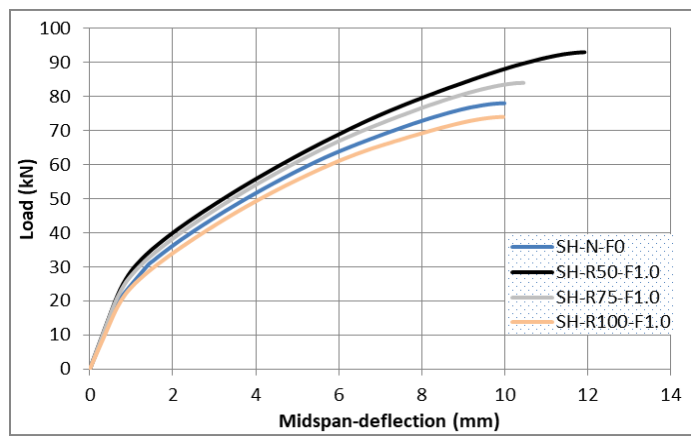

Figure 6: Effect of (1.0)\% Steel fiber with $(100,75,50) \%$ RA content on the Load-Defection Curve

Figure 7 shows the effect of $(0.5,1.0$, and 2.0$) \%$ steel fiber content on the load-defection curve. Compared with the nonfibrous $100 \%$ RA concrete specimen, there is an improvement in reducing the mid span deflection with the increase of the steel fiber content. Figure 8.shows the effect of the internal diaphragms on the load-defection curve. In comparison with the nonfibrous $100 \%$ RA concrete specimen, the addition of diaphragms' in the middle third of the box girder span gives a significant effect in reducing the mid-span deflection. 


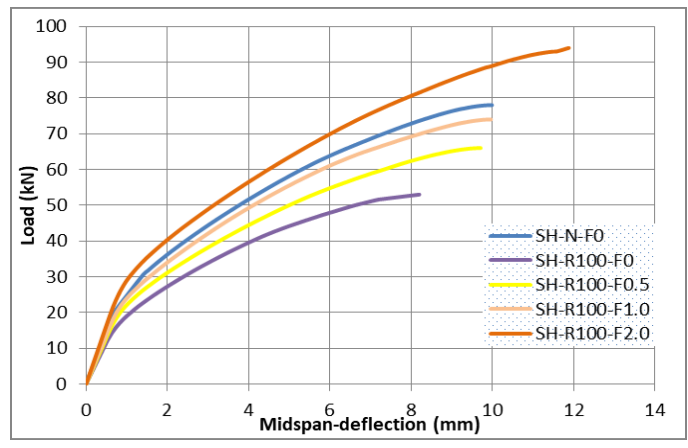

Figure 7: Effect of $(0.5,1.0,2.0) \%$ Steel fibre content on The Load-Defection Curve

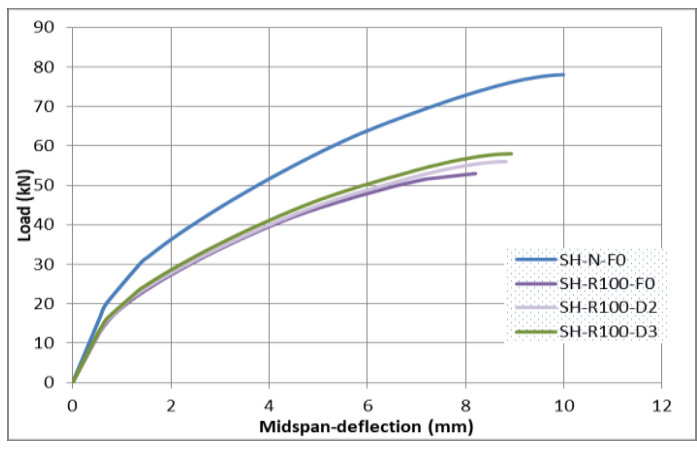

Figure 8: Effect of Diaphragms' numbers on The Load-Defection Curve

\subsection{Load-strain behavior}

To investigate the load-strain behavior of the box girder, six concrete surface strain gauges were installed at the shearspans, three in each spannamed as SG1,SG2, and SG3respectively.Figures 9.to 19 show the concrete strain of the box girder specimens for the different loading levels. It is obvious that the strain values for the RA concrete specimen increases as the percent of the RA increase compared to the NA concrete specimen under same increment loading. In contrast, the strain values decrease as the percent of the steel fiber increase when compared with its reference specimen. On the other hand, the addition of the $(60 \mathrm{~mm})$ internal diaphragms in the flexural zone contributes in increase the strain values to some extend compared with the reference specimen.

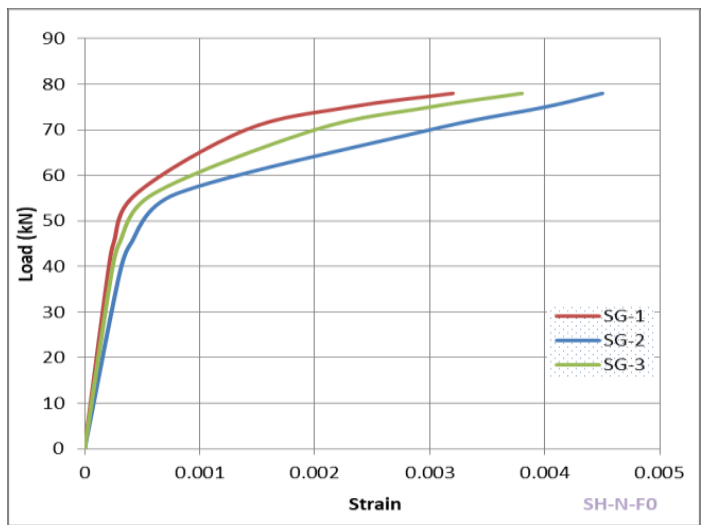

Figure 9: Concrete surface strains for the control specimen $(\mathrm{SH}-\mathrm{N}$ F0)

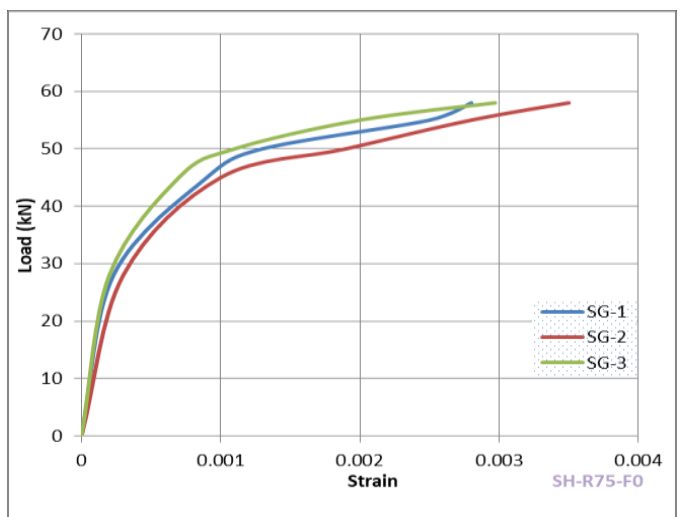

Figure 11: Concrete surface strains for the specimen (SH-R75-F0)

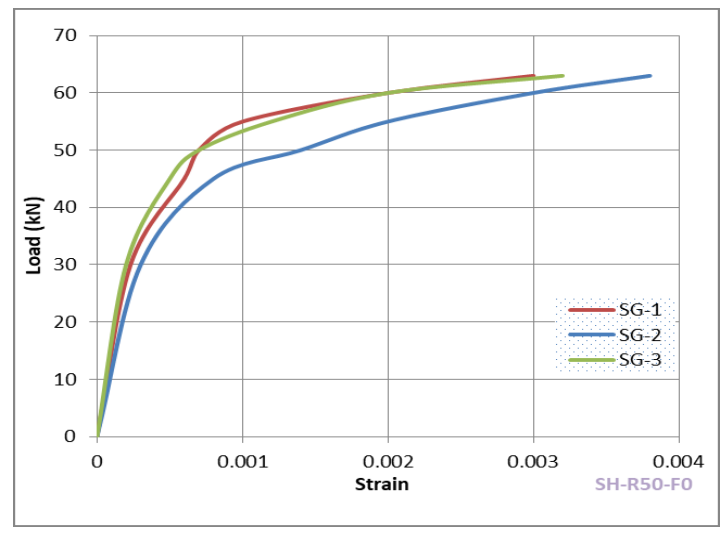

Figure 10: Concrete surface strains for the specimen (SH-R50-F0)

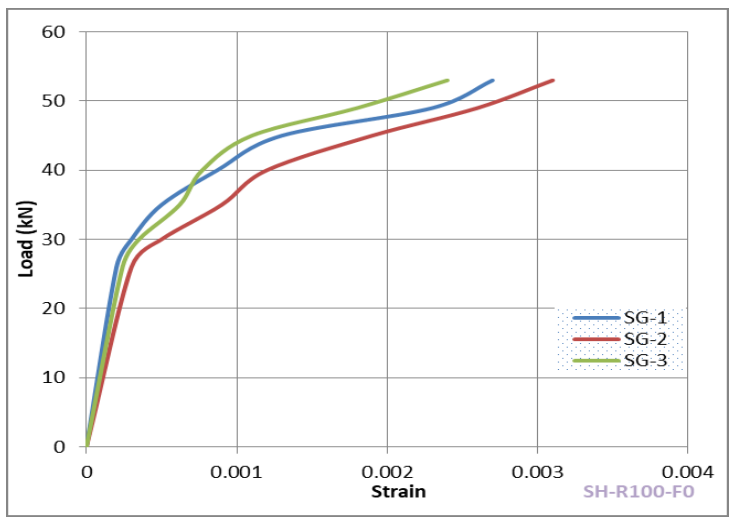

Figure 12: Concrete surface strains for the specimen(SH-R100-F0) 


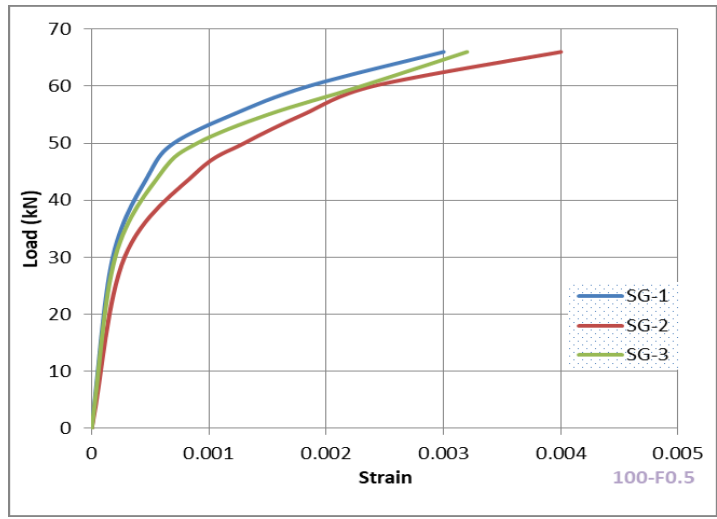

Figure 13: Concrete surface strains for the specimen (SH-R100F0.5)

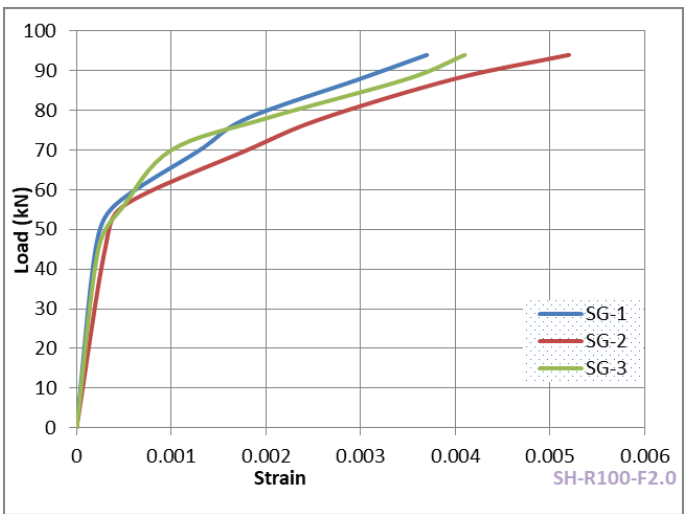

Figure 15: Concrete surface strains for the specimen (SH-R100 F2.0)

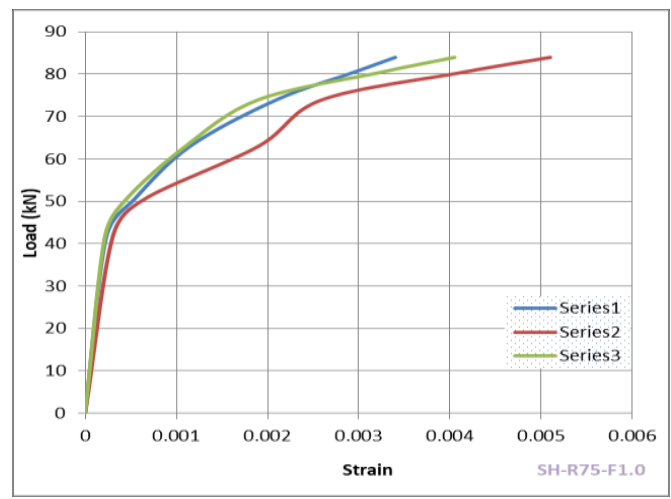

Figure 17: Concrete surface strains for the specimen(SH-R50-F1.0)

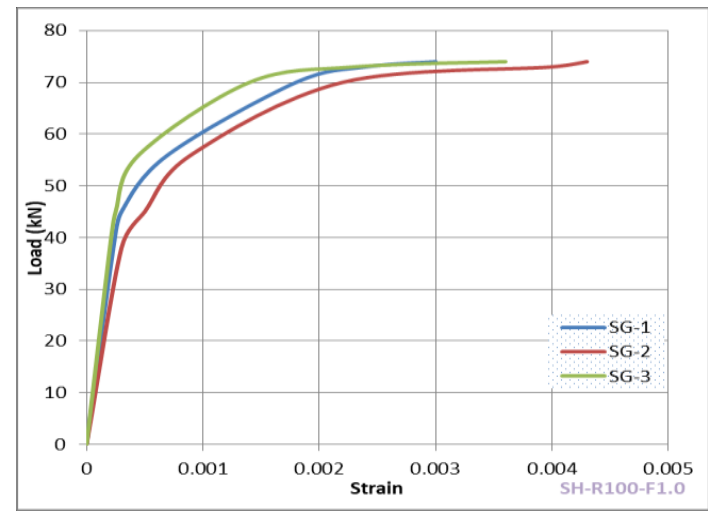

Figure 14: Concrete surface strains for the specimen (SH-R100F1.0)

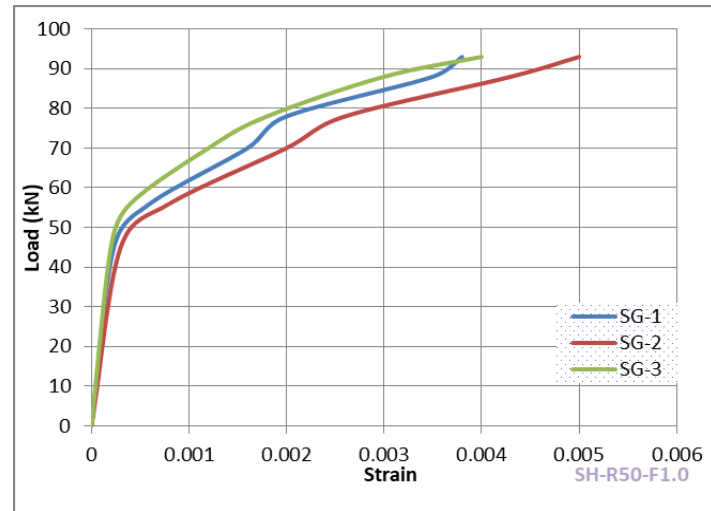

Figure 16: Concrete surface strains for the specimen (SH-R75-F1.0)

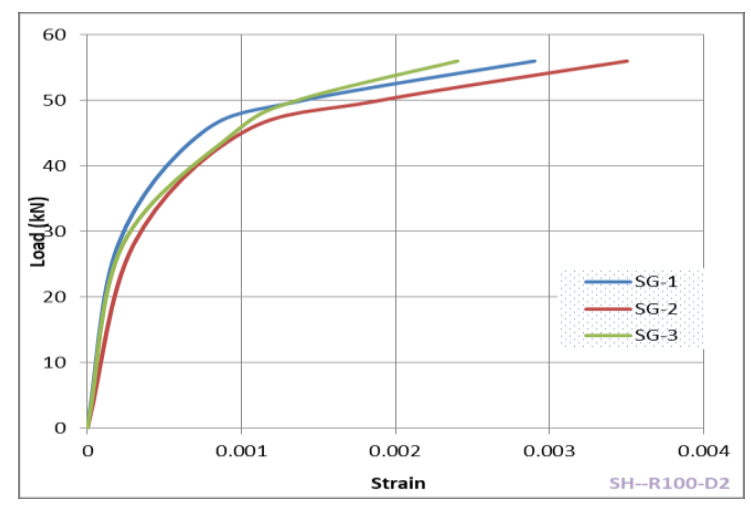

Figure 18: Concrete surface strains for the specimen (SH-R100-D2) 


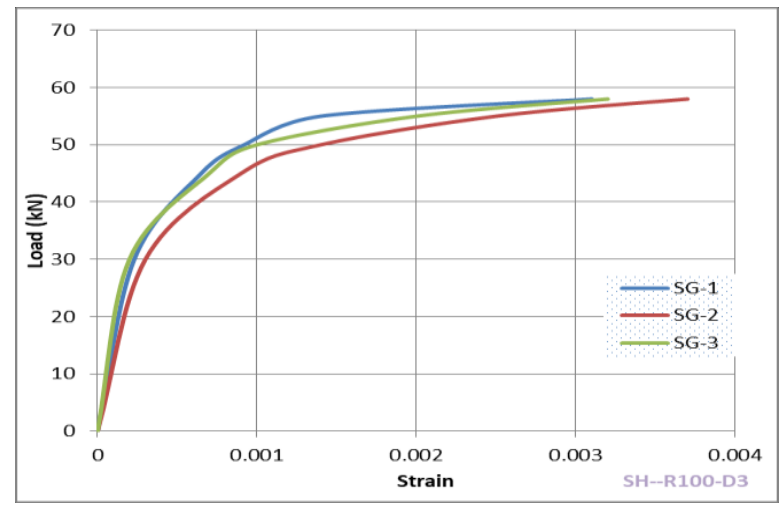

Figure 19: Concrete surface strains for the specimen (SH-R100-D3)

\subsection{Cracks and failure modes}

For specimen (SH-N-F0); which was made from 100\% natural coarse aggregate and without steel fibers (control), the initiation observed crack was a flexural crack in the lower flange. While the loading increased an inclined shear cracks started to appear in the web at the shear zone. For further loading, the inclined cracks propagate successively in the web and extend to the upper flange and lower flange. As loading increased, these cracks increased in expanding and combined with each other. Finally, the collapse occurred suddenly due to the shear force in shear zone of the box girder at load $78 \mathrm{kN}$. Figure 20 shows the failure mode for the specimen.

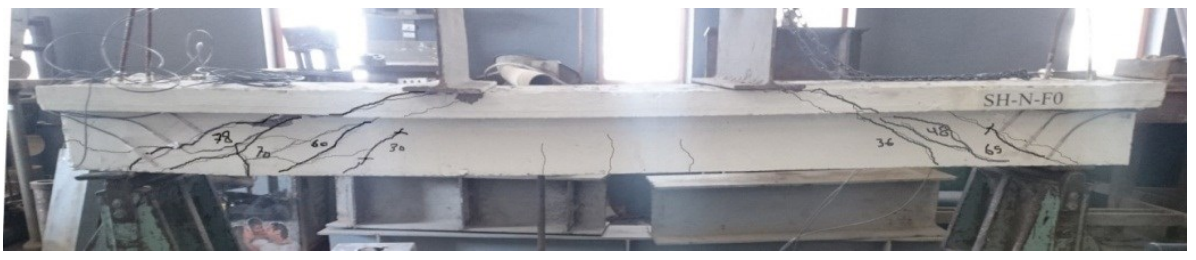

Figure 20: Crack patterns and failure mode for the box girder SH-N-F0

For specimens, (SH-R50-F0, SH-R75-F0, and SH-R100-F0), which made from $(50,75$, and 100) \% recycled coarse aggregate respectively, and without steel fibers. The initiation cracks were observed in the region between the two load lines in the lower flange. While the loading increased, narrow and small inclined shear cracks appeared in the web through the shear zone. For further loading, the inclined cracks propagate successively in the web and extend to the upper flange and lower flange. As loading increased, these cracks increased in expanding and combined with each other. Finally, the collapse occurred suddenly due to the shear force in shear zone of the box girdersSH-R50-F0, SH-R75-F0, and SH-R100-F0at load (63,58, and $53) \mathrm{kN}$ respectively. Figures21,22, and 23.show the failure mode for these beam specimens.

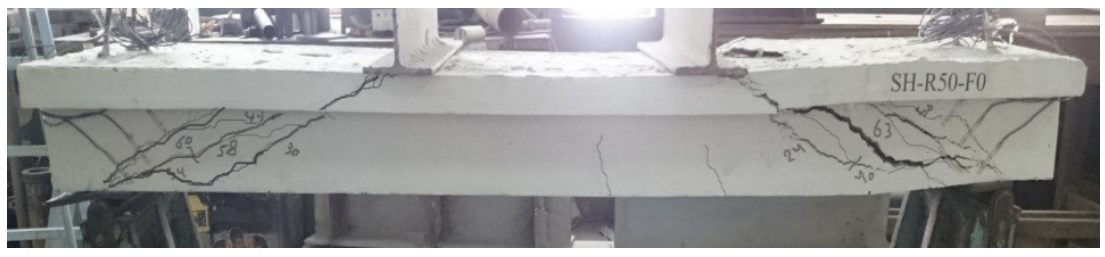

Figure 21: Crack patterns and failure mode for the box girder SH-R50-F0

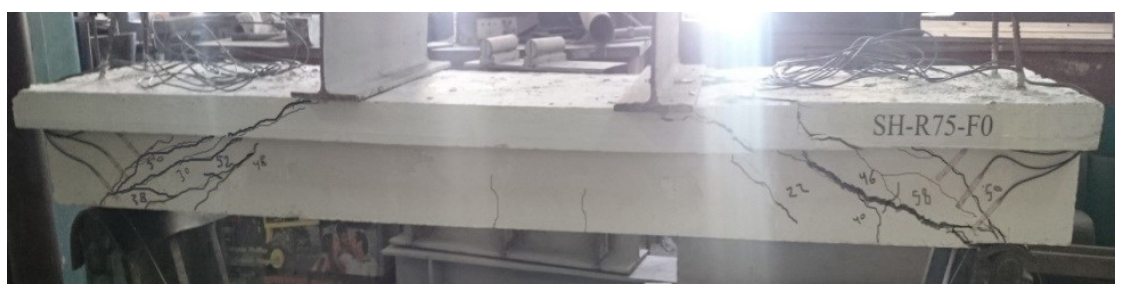

Figure 22: Crack patterns and failure mode for the box girder SH-R75-F0 


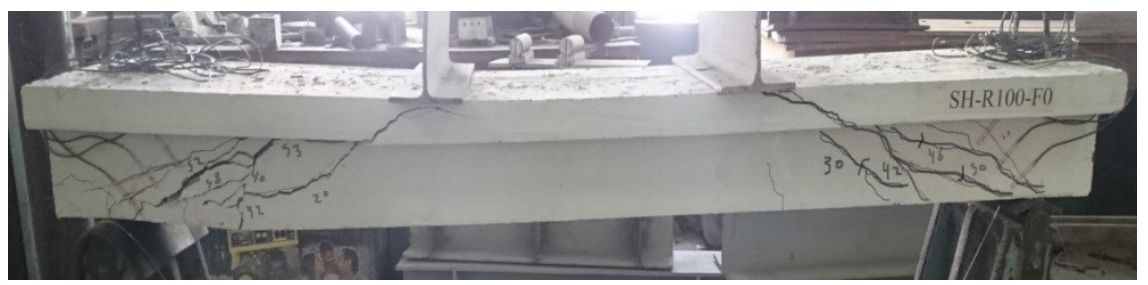

Figure 23: Crack patterns and failure mode for the box girder SH-R100-F0

For specimens, SH-R100-F0.5, SH-R100-F1.0, and SH-R100-F2.0), which made from (100) \% recycled coarse aggregate, and with steel fiber ratios of $(0.5,1.0,2.0) \%$ respectively. The initiation cracks were observed in the flexural region. While the loading increased, narrow and small inclined cracks appeared in the shear zone at the web. For further loading, the inclined shear cracks propagate successively in the web and extend to the upper flange and lower flange. As loading increased, these cracks increased in expanding and combined with each other. Finally, the collapse occurred suddenly due to the shear force in shear zone of the box girdersSH-R100-F0.5, SH-R100-F1.0, and SH-R100-F2.0 at load (66,74, and 94)kNrespectively. Also, it can be notice that, the number of cracks reduced with the increasing of volumetric ration $\left(\mathrm{V}_{\mathrm{f}}\right)$ of steel fibers. Figures 24,25 , and 26 show the failure mode for these beam specimens.

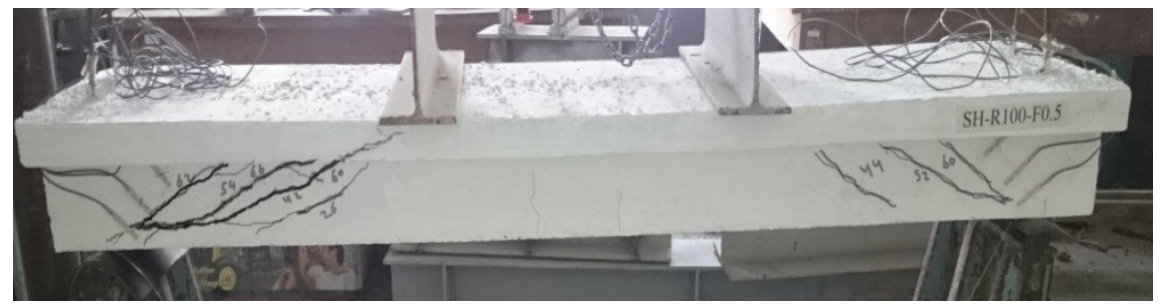

Figure 24: Crack patterns and failure mode for the box girder SH-R100-F0.5

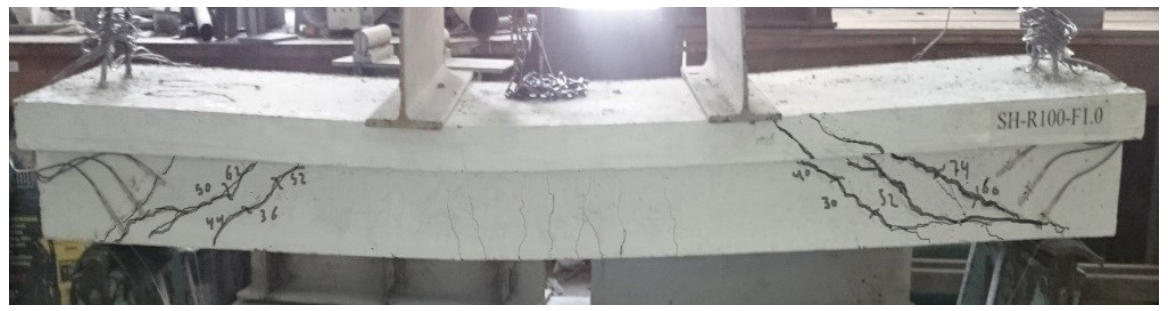

Figure 25: Crack patterns and failure mode for the box girder SH-R100-F1.0

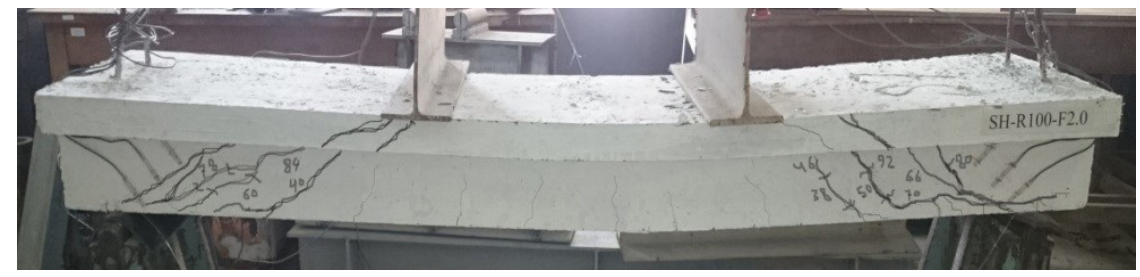

Figure 26: Crack patterns and failure mode for the box girder SH-R100-F2.0

For Specimens, (SH-R75-F1.0, and SH-R50-F1.0), which made from (75, and 50) \% recycled coarse aggregate, respectively, and with steel fiber ratio of (1.0) \%. The initiation cracks were observed in the flexural region. While the loading increased, narrow and small inclined shear cracks appeared in the shear zone at the web. For further loading, the inclined shear cracks propagate successively in the web and extend to the upper flange and lower flange. As loading increased, these cracks increased in expanding and combined with each other. Finally, the collapse occurred suddenly due to the shear force in shear zone of the box girders SH-R75-F1.0, and SH-R50-F1.0 at load 84, and 93kN respectively. Figure 27 and 28 illustrate the failure mode for these specimens. 


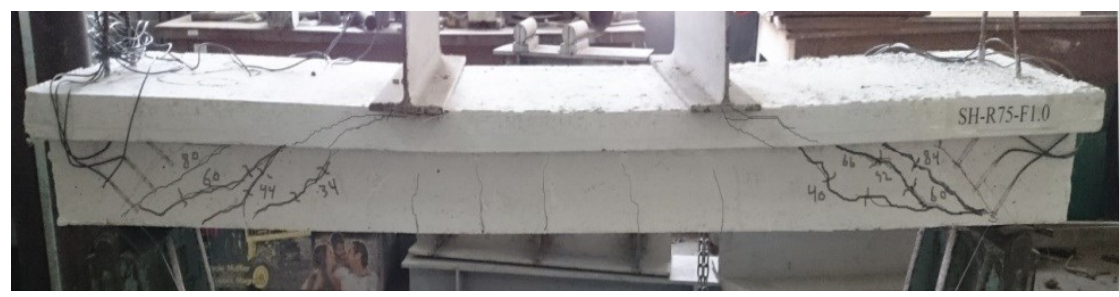

Figure 27: Crack patterns and failure mode for the box girder SH-R75-F1.0

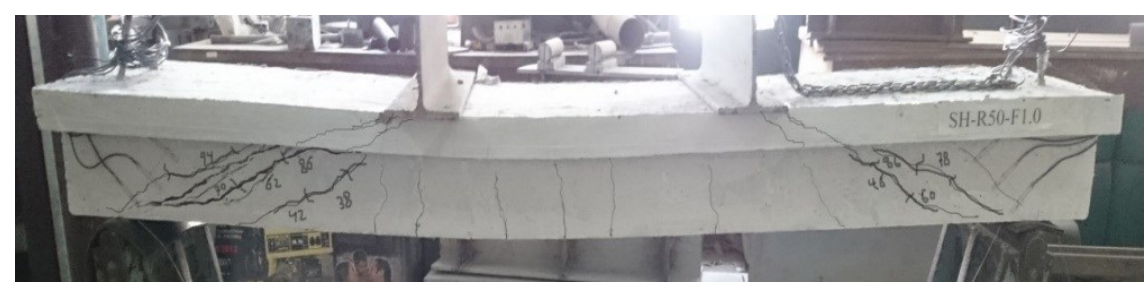

Figure 28: Crack patterns and failure mode for the box girder SH-R50-F1.0

For specimens, SH-R100-D2, and SH-R100-D3 which made from (100) \%) recycled coarse aggregate, and without steel fiber. Two $60 \mathrm{~mm}$ diaphragms used for specimen SH-R100-D2 and three diaphragms for the specimen SH-R100-D3. The cracks were initiated in the region between the two load lines, in the lower flange and between the diaphragm's points (the strength increased in the diaphragms points). While the loading increased, narrow and small inclined shear cracks appeared in the web through the shear zone. For further loading, the inclined shear cracks propagate successively in the web and extend to the upper flange and lower flange. As loading increased, these cracks increased in expanding and combined with each other. Finally, the collapse occurred suddenly due to the shear force in shear zone of the box girdersSH-R100-D2, and SH-R100-D3 at load $56 \mathrm{kN}$, and $58 \mathrm{kNrespectively.} \mathrm{Figures} 29$ and 30 illustrate the failure mode for these specimens.

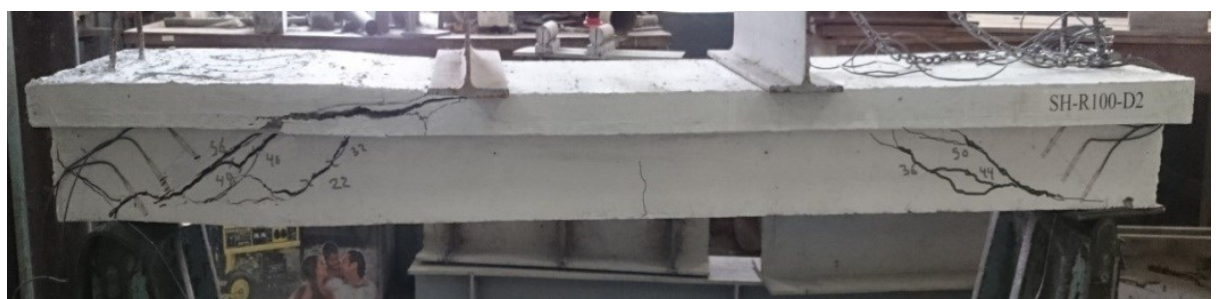

Figure 29: Crack patterns and failure mode for the box girder SH-R100-D2

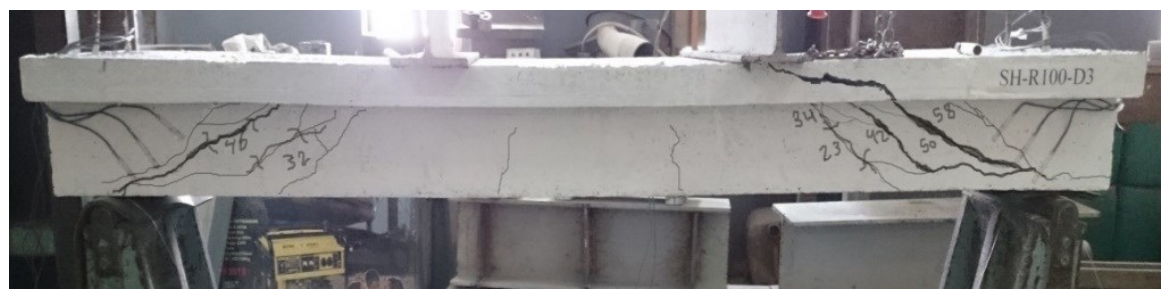

Figure 30: Crack patterns and failure mode for the box girder SH-R100-D3

\section{Conclusions}

1) The recycled aggregate concrete mix shows decrease in the cylindrical compressive strength, splitting tensile strength, flexural strength, and elastic modulus of concrete when compared with the NA concrete mix, this decrement increases with increasing the percent of RA.On the other hand, adding steel fibers considerably enhanced the mechanical properties of the RA concrete. Therefore, the mechanical properties increase with increasing the percent of steel fiber from 0.5 to 2.0.

2) The result show that the RA has a significant effect on the load capacity of the box girder without steel fibres, the decreases in the cracking load are $(33,27$, and 20$) \%$ for the RA of $(100,75$, and 50) $\%$ respectively as compared to the control beam. Also, the corresponding values of strengthening for same RA mixed by $1.0 \%$ steel fibres are about $(3,13$, and 27$) \%$, respectively.

3) For the non-fibrous (100) \% RA box girder, the strengthening by steel fibreshas a significantly effective in increasing the first cracking load. The percentage increase is approximately $(30,55$, and 90$) \%$ for $(100) \%$ 
RA concrete with steel fiber ratio of $(0.5,1.0$,and 2.0$) \%$, respectively. While, the percentage increase in the strengthening with using the internal (two and three) diaphragms was about (10, and 15$) \%$ for the $100 \%$ RA concrete specimen respectively compared to control beam.

4) The overall shear strength is affected by the RA content compared with the control specimen, the percentage decrease in the ultimate load were $(32,25$, and 19$) \%$ for the RA with $(100,75$, and 50$) \%$ of steel fiber content respectively. Also, the corresponding values of strengthening for same RA mixed by $1.0 \%$ steel fibres are about $(-5,+8$, and +19$) \%$, respectively.

5) For the non-fibrous (100) \% RA box girder, the strengthening by steel fibershas significantly effective in increasing the ultimate load. The increase is $(25,40$, and 77$) \%$ for $(100) \%$ RA concrete with steel fiber ratio of $(0.5,1.0$,and 2.0$) \%$, respectively. While, the strengthening by the internal (two and three) diaphragms is about (6, and 9) $\%$ for the $100 \%$ RA concrete specimen respectively.

6) The strain values for the RA concrete box girder specimen increases as the percent of RA increases compared with NA concrete specimen. In contrast, the strain values decrease as the percent of steel fiber increase when compared with its reference specimen. Furthermore, the addition of the $(60 \mathrm{~mm})$ diaphragms in flexural zone contributed in decrease the strains compared with the convention concretespecimen.

7) From the test results, and to retain the NA concrete strength when use $100 \% \mathrm{RA}$, it is recommended to use Vf of $(1.0 \%)$.

\section{References}

[1] S. C. Kumar,V. K. Varanasi, and P. Saha,"Sustainable development usingsupplementarycementitiousmaterials and recycled aggregate," International Journal of Modern Engineering Research (IJMER),Vol. 2, Issue.1, pp.165-171, 2015

[2] V. Radonjanin, M. Malešev, S. Marinkovic, and A. E. S. Al Malty, "Green recycled aggregate concrete," Construction and Building Materials, Vol.47, pp. 1503-1511,2013.

[3] A. M. Wagih, H. Z. El-Karmoty, M.Ebid, and S. H. Okba, "Recycled construction and demolition concrete waste as aggregate for structural concrete." HBRC Journal, Vol.9, pp. 193-200, 2013.

[4] F. Debieb, L. Courard, S. Kenai, and R.Degeimbre "Mechanical and durability properties of concrete using contaminated recycled aggregates," Cement and Concrete Composites, Vol.32, pp.421-426, 2010.

[5] E.K. Sayhood, A.S. Resheq, and F.L. Raoof "Behavior of Recycled Aggregate Fibrous Reinforced Beams Under Flexural and Shear Loading" Engineering and Technology Journal, Vol. 37, Part C, No. 3, 2019

[6] M.A.E. Al Hamdani, M.M. Hamid and N.M. Al Hussiny, "The Influence of Recycled Crushing Strength of RC Beams under Repeated Loading,” Engineering and Technology Journal, Vol. 37, Part C, No. 1, pp. 93-100, 2019.

[7] V.Corinaldesi "Mechanical and elastic behaviour of concretes made of recycled-concrete coarse aggregates," Construction and Building Materials, Vol.24, pp.1616-1620, 2010.

[8] A.M. Knaack, Y. C. Kurama, "Design of normal strength concrete mixtures with recycled concrete aggregates," ASCE, pp.3068-3079, 2014.

[9] Y. Guo, J. Zhang, G. Chen,andZ. Xie, "Compressive behaviour of concrete structures incorporating recycled concrete aggregates," structural material J, Vol.60, pp. 78-96, 2014

[10] S. J. K. Al-Obaidy, "The Effects of Using Steel Fibers on Self-Compacting Concrete Properties: A Review," Engineering and Technology Journal, Vol. 38, Part A, No. 11, pp. 1666-1675, 2020.

[11] A.Upadhyay, and S.Maru "Comparative Study of PSC Box Girder Multi Cell (3- Cell) Bridge of Different Shapes: A Review Paper," Global Research and Development Journal for Engineering, Volume 2 , 2017.

[12] S. Manzi, C. Mazzotti, and M. C. Bignozzi, "Self-compacting concrete with recycled concrete aggregate: study of the long-term properties," constructioin and building materials, Vol.157,pp. 582-590, 2017

[13] R. T. Abdulkareem, M. S.Hassan, I. N. Gorgis, "Effect of Steel Fibers, Polypropylene Fibers and/ or Nanosilicaon Mechanical Properties of Self-Consolidating Concrete" Engineering and Technology Journal, Vol. 34, Part A, No. 3, pp. 527-538, 2016.

[14] Iraqi Specification, No. 5, "Portland Cement" Baghdad,1984.

[15] Iraqi Specification, No. 45, “Aggregate from Natural Sources for Concrete and Construction”Baghdad,1984.

[16] American Society of Testing and Materials, "Standard Specifications for Concrete Aggregates," ASTM C 33/C 33M-08, West Conshohocken, 2008.

[17] AASHTO LRFD Bridge Design Specifications" American Association of State Highway and Transportation Officials, USA, Fifth Edition, 2012. 
[18] ACI committee 318, Building Code Requirements for Structure Concrete, (ACI 318M-14) and Commentary (ACI 318RM-14), American Concrete Institute, Farmington Hills, Michigan 2014.

[19] The European Federation of Specialist Construction Chemicals and Concrete Systems (EFNARC), “The European Guidelines for Self- Compacting Concrete; Specification, Production and Use".2005.

[20] ASTM C 39/C 39M-05, "Standard Test Method for Compressive Strength of Cylindrical Test Specimens", Vol. 04.02, 2005, 9 pp.

[21] ASTM C496/C 496M-04, "Standard Test Method for Splitting Tensile Strength of Cylindrical Concrete Specimens", Vol. 04.02,2004, $5 \mathrm{pp}$.

[22] ASTM C 78-02, "Standard Test Method for Flexural Strength of Hydraulic- Cement Mortars”, Vol. 04.02, 2002,6 pp.

[23] ASTM C469-02 "Standard specification for testing method for static modulus of elasticity and poison's ratio of concrete in compression", Annual Book of ASTM Standards, American Society for Testing and Material, Philadelphia, Pennsylvania, Section 4, Vol.(4.02), pp 236-239, 2002. 